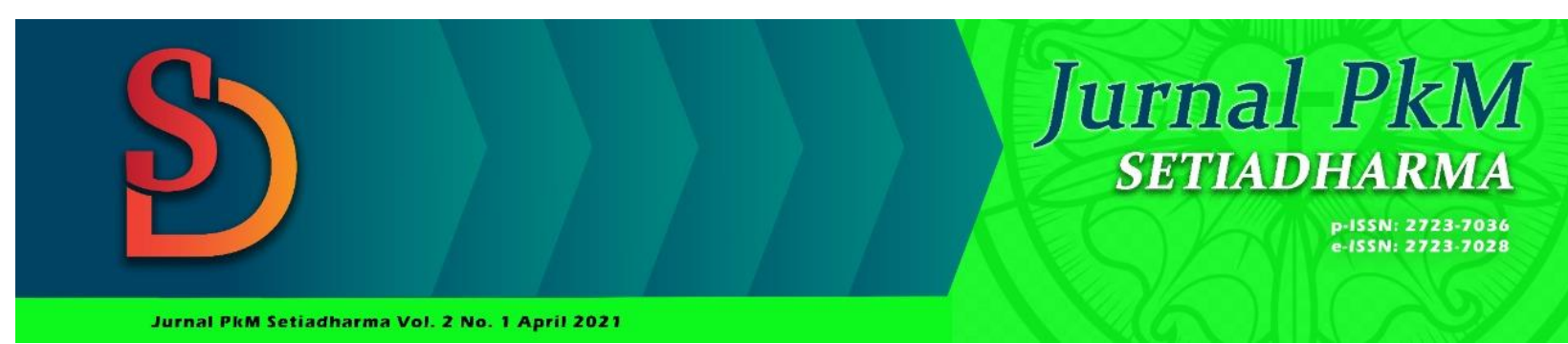

\title{
PERANAN KEMITRAAN GEREJA DENGAN LEMBAGA KRISTEN DALAM MENINGKATKAN PENDAPATAN JEMAAT
}

\author{
Jamsen Ginting, ${ }^{1}$ Yanto Paulus Hermanto, ${ }^{2}$ Ferry Simanjuntak ${ }^{3}$ \\ jginting11@gmail.com, yantopaulush@gmail.com, ferrysimanjuntak76@gmail.com \\ Sekolah Tinggi Teologi Kharisma Bandung
}

Diterima:
19-01-2021
Direview:
06-02-2021
11-03-2021

Direvisi:
11-02-2021
22-03-2021
Diterbitkan:
30-04-2021
Keywords:
role, partnership,
church, Christian
institution

\section{Abstract}

Poverty in Indonesia is still evident in areas with a large population of Christians. According to the data from the Central Bureau of Statistics in 2020, the provinces of Papua, Maluku and NTT are areas with a high percentage of population poverty rates. Even though in these areas the church has been serving the people for a long time. The existence of the church in the midst of society wherever it is is expected to be able to answer the problem of poverty that plagues church congregants and society in general. Churches that serve in poor community face challenges in playing an active role in increasing congregational income. The limited resources owned by the church and the limited financial support of congregational make the church unable to serve the congregation maximally in terms of supporting the increase in the income of the congregation who are still living in poverty. Unlike the case with churches that have good resources such as human resources and strong financial resources. Realizing the limited resources owned by the church, it is necessary to involve third parties from outside the church and the congregation to equip and provide support to the church in developing the economic potential of the congregation. Keeping Christ-centered Christian values from being degraded, the church builds partnership with institutions that have the same service values as the church and have the same goal of increasing the income of congregation. Cooporation can be carried out through partnerships to achieve common goals to increase income of congregation. Each party has rights and obligations that support each other in the partnership that is built.

\section{Abstrak}

Kemiskinan secara ekonomi di Indonesia masih tampak dengan jelas berada di wilayahwilayah dengan populasi penduduk yang banyak beragama Kristen. Menurut data Badan Pusat Statistik tahun 2020 provinsi Papua, Maluku, dan NTT merupakan wilayah dengan persentasi tingkat kemiskinan penduduk yang tinggi. Padahal di wilayah-wilayah ini gereja

\footnotetext{
${ }^{1}$ Mahasiswa Program Magister Teologi Sekolah Tinggi Teologi Kharisma Bandung.

2 Dosen Prodi Karya Tulis Ilmiah Program Magister Teologi Sekolah Tinggi Teologia Kharisma Bandung.

3 Dosen Wali Program Magister Teologi Sekolah Tinggi Teologi Kharisma Bandung.
} 
sudah melayani umat sejak lama. Keberadaan gereja di tengah-tengah masyarakat di manapun berada diharapkan dapat menjawab permasalahan kemiskinan yang mendera jemaat gereja secara khusus dan masyarakat pada umumnya. Gereja yang melayani di lingkungan masyarakat miskin mengahadapi tantangan dalam berperan aktif untuk meningkatkan penghasilan jemaat. Keterbatasan sumber daya yang dimiliki oleh gereja dan dukungan jemaat dalam keuangan yang terbatas membuat gereja tidak dapat melayani jemaat dengan maksimal dalam hal mendukung peningkatan penghasilan jemaat yang masih hidup dalam kemiskinan. Berbeda halnya dengan gereja yang memiliki sumbersumber daya yang baik seperti sumber daya manusia dan sumber daya keuangan yang kuat. Menyadari keterbatasan sumber daya yang dimiliki oleh gereja, maka perlu melibatkan pihak ketiga dari luar gereja dan jemaat untuk memperlengkapi dan memberi dukungan kepada gereja dalam mengembangkan potensi ekonomi jemaat. Menjaga nilainilai kekristenan yang berpusat pada Kristus agar tidak terdegradasi, maka gereja membangun kerjasama dengan lembaga yang memiliki nilai-nilai pelayanan yang sama dengan gereja dan tujuan yang sama meningkatkan pendapatan jemaat. Kerjasama dapat dilakukan melalui kemitraan untuk mencapai tujuan bersama yaitu meningkatkan pendapatan jemaat. Masing-masing pihak memiliki hak dan kewajiban yang saling mendukung dalam kemitraan yang dibangun.

\section{PENDAHULUAN}

Krisis global mulai melanda banyak negara akibat dampak dari pandemi Covid-19 yang masih terjadi. Dunia usaha mulai merasakan melambatnya laju pertumbuhan ekonomi, bahkan mencapai titik terendah di beberapa sektor dan mengalami penurunan seperti sektor pariwisata, tekstil, properti, dan sektor-sektor lainnya. Resesi ekonomi global berdampak besar terhadap pendapatan perkapita masyarakat termasuk jemaat gereja. Ada yang mengalami pemotongan gaji, pemutusan hubungan kerja, usaha berhenti dan mengalami kerugian. Lebih ironis korupsi masih merajalela sehingga tidak mengherankan dampak dari korupsi dapat menimbulkan runtuhnya ekonomi sebuah bangsa. Tingginya tingkat korupsi suatu negara mengakibatkan semakin besar dan semakin cepat ekonomi suatu negara yang mengarah pada krisis moneter. Bahkan korupsi juga merusak tatanan ekonomi negara, menghambat pembangunan, serta menyebabkan sistem akuntabilitas keuangan sebuah bangsa menjadi tidak stabil. ${ }^{4}$ Bagi jemaat gereja yang selama ini hidup di bawah garis kemiskinan dengan penghasilan di bawah upah minimum regional setempat, semakin sulit meningkatkan pendapatan dan keluar dari kemiskinan. Jemaat gereja yang hidup dalam kemiskinan sangat menantikan uluran tangan dari semua pihak yang berkenan membantu mereka, terutama dari gereja di mana mereka berjemaat saat ini.

Gereja sendiri saat ini mengalami penurunan pemasukan keuangan dari persembahan jemaat yang sangat drastis. Gereja sendiri mengalami kesulitan mengatasi biaya operasional karena persembahan rutin berkurang, donatur gereja mulai menahan diri dalam memberi bantuan karena berbagai alasan yang menyangkut ketersediaan dana yang terbatas. Gereja yang selama ini mapan secara keuangan mulai beradaptasi terhadap

4 Petrus Simon, "Tanggapan Alkitab Terhadap Wacana Hukuman Mati Bagi Pelaku Korupsi," Kenosis 6 (2020): 109, https://e-journal.iaknambon.ac.id/index.php/KNS/article/view/87/126 
PERANAN KEMITRAAN GEREJA DENGAN LEMBAGA KRISTEN ... (Jamsen Ginting, Yanto Paulus

Hermanto, Ferry Simanjuntak)

keuangan yang ada, sementara gereja yang selama ini sangat minim secara keuangan terus mencari cara dalam memenuhi kebutuhan gereja agar tetap bisa melayani jemaat.

Kompleksitas dampak resesi global membuat kecenderungan perilaku dalam bertahan hidup adalah menyelamatkan diri sendiri. Pembatasan interaksi individu dan kelompok masyarakat mendorong orang untuk melakukan apa saja yang dapat dilakukan agar memiliki dan meningkatkan pendapatan. Jemaat berharap bantuan dari gereja untuk meringankan beban merea namun gereja tidak dapat menolong karena gereja juga mengalami hal yang sama. Penulis melihat gereja sebagai organisasi memiliki jangkauan luas dan strategis dalam menemukan kesempatan bagi jemaat melalui kerjasama kemitraan dengan organisasi lain yang dapat membantu gereja dan jemaat dalam pendampingan pelatihan dan keterampilan, penyediaan saranan dan prasarana, dukungan modal usaha dan memperluas jaringan dengan pihak-pihak lain yang memiliki nilai dasar yang sejalan seperti Lembaga Kristen. Lembaga Kristen yang dimaksud dalam tulisan ini adalah sebuah Lembaga berkedudukan di Bandung yang bergerak dalam bidang pengembangan di mana penulis bergabung. Kerjasama kemitraan akan memperlengkapi gereja, memperluas daya jangkau gereja dan salah satunya memampukan gereja menolong jemaat dalam peningkatan pendapatan dengan menggali dan mengelola sumber daya ekonomi lokal di mana gereja dan jemaat tinggal. Sekarang waktunya gereja untuk menjangkau dunia luas tanpa batas untuk memberitakan Injil dan mengakses sumbersumber daya global yang mendukung pelayanan gereja.

Hasil pengamatan di jemaat gereja ditemukan beberapa identifikasi masalah sebagai berikut: kesatu, krisis global melanda dunia; kedua, korupsi masih merajalela; ketiga, jemaat mengalami penurunan pendapatan; keempat, jemaat tidak memiliki sumber penghasilan; kelima, gereja mengalami penurunan persembahan; keenam, meningkatnya sikap mementingkan diri sendiri; ketujuh, gereja tidak mampu meringankan kesulitan jemaat. Berdasarkan identifikasi masalah yang telah dilakukan, penulis memberikan batasan masalah sebagai berikut: kesatu, bagaimana meningkatkan penghasilan jemaat yang sedang tidak memiliki sumber penghasilan? kedua, apa peran gereja untuk menolong jemaat di masa resesi? Kita tidak selalu dapat memilih apa yang terjadi pada kita. Seringkali kita tidak dapat mengontrol apa yang seseorang lakukan kepada kita seperti seorang atasan, seorang pasangan, seorang anak, pengendara yang mengganggu, rekan bisnis yang tidak jujur. Tapi kita dapat mengendalikan reaksi kita. Dan kita akan memili sesuatu. ${ }^{5}$

Penelitian yang dilakukan oleh penulis memiliki tujuan: pertama, untuk mengetahui cara meningkatkan pendapatan jemaat melalui kerjasama kemitraan; kedua, meningkatkan peran gereja melayani jemaat di masa sukar. Melalui penelitian ini diharapkan ada manfaat yang akan dicapai yaitu, kesatu secara teoritis memberikan kontribusi ilmu pengetahuan kepada gereja dalam menolong jemaat di masa krisis ekonomi; kedua, jemaat semakin bertumbuh dalam iman ketika gereja mendampingi jemaat mengatasi masalah keuangan.

\section{METODE PELAKSANAAN}

Penelitian ini dilakukan dengan metode pelaksanaan kegiatan pengabian masyarakat. Sebelum melakukan sebuah penelitian dengan metode pelaksanaan, perlu dipahami arti dari metode penelitian yang digunakan agar proses penelitian dilakukan dengan benar dan tujuan penelitian dapat tercapai. Kata metode dan logos yang terkandung dalam metodologi memiliki arti cara tepat untuk melakukan sesuatu dan ilmu atau pengetahuan. Penelitian merupakan bentuk suatu kegiatan menemukan, menulis, membuat rumusan dan

${ }^{5}$ Jeff Manion, The Land Between: Finding God in Difficult Situation (Michigan: Zondervan, 20012). 
melakukan analisis hingga membuat laporan' ${ }^{6}$ Kata 'metode' dan 'metodologi' sering dicampuradukkan dan disamakan. Padahal keduanya memiliki arti yang berbeda. Kata 'metodologi' berasal dari kata Yunani 'methodologia' yang berarti 'teknik' atau 'prosedur'. Penelitian disebut sebagai metodologi ketika mengacu kepada pemikiran umum yang menyeluruh dan gagasan teoritis. Metode mengacu pada penggunaan teknik penelitian yang mencakup observasi, wawancara dan survei. ${ }^{7}$ Sehubungan dengan penelitian yang akan dilakukan, metode yang digunakan adalah Metode Pelaksanaan dengan penjelasan pelaksanaan kegiatan. Analisis data dapat dilakukan dengan menggunakan penjelasan rinci tentang data sosial yang ditemukan, dan kemudian membuat beberapa kesimpulan sementara. Penulis menggunakan data dari hasil wawancara, observasi, dokumen tertulis yang dianalisis secara deskriptif dengan mendeskripsikan fakta, kemudian dianalisis dan dijelaskan. Secara ilmiah penulis mendapatkan data dan informasi melalui penelitian untuk mengetahui pencapaian tujuan dalam implementasi kerjasama kemitraan dan manfaatnya bagi gereja, jemaat dan masyarakat. Data dari pengamatan terdiri dari deskripsi rinci tentang aktivitas orang, perilaku, tindakan, dan berbagai interaksi interversonal dan proses organisasi yang merupakan bagian dari pengalaman manusia yang dapat diamati. Berdasarkan data yang diperolah ditarik satu kesimpulan baru tentang kemitraan.

Penelitian dilakukan dengan metode pelaksanaan berhubungan dengan peran gereja menjawab kerinduan jemaat gereja lokal di daerah Pati, Purbalingga dan Ungaran dalam meningkatkan penghasilan jemaat. Metode Pelaksanaan mengacu pada kemampuan menyelesaikan pekerjaan secara sistematis dari awal pengumpulan data sampai akhir kegiatan melalui tahapan kegiatan dan cara kerja setiap kegiatan yang dilakukan dengan pertanggungjawaban yang jelas. Pengumpulan data dilakukan dengan melakukan: kesatu, wawancara terbuka dengan pemimpin gereja dan jemaat. Penulis mendapatkan data informasi tentang penghasilan jemaat yang masih rendah, ketergantungan jemaat pada pemilik modal, dan ketidakmampuan gereja membantu jemaat dalam hal keuangan. Kedua, Penulis melakukan pengamatan langsung melihat potensi ekonomi yang dimiliki jemaat di desa mereka tinggal. Penulis mendapatkan data bahwa jemaat memiliki potensi di bidang pengolahan bawang merah, pengolahan kebun untuk menanam sayur-sayuran, dan usaha rumah tangga membuat kaos. Ketiga, data dokumen tertulis dibuat oleh pemimpin dan staf gereja dalam bentuk proposal pengajuan dana untuk program pemberdayaan jemaat dalam rangka meningkatkan penghasilan jemaat gereja yang diajukan kepada Lembaga Kristen. Setelah melakukan survei dan verifikasi kelayakan program, Lembaga Kristen mencari donatur yang mau mendanai program yang diajukan gereja. Ketika Lembaga Kristen mendapatkan donatur untuk mendanai program tersebut, dana langsung dikirim ke rekening gereja dan bersama dengan perwakilan Lembaga Kristen yang mendampingi, pemimpin gereja mempersiapkan pelaksaan program yang sudah direncanakan. Melalui penelitian ini tujuan yang ingin dicapai, pertama, untuk mengetahui cara meningkatkan pendapatan jemaat melalui kerjasama kemitraan; kedua, meningkatkan peran gereja melayani jemaat di masa sukar; akan terealisasi setelah program ini berjalan.

\section{PEMBAHASAN DAN HASIL}

Melalui ayat-ayat dalam Alkitab dapat dilihat bahwa manusia harus berusaha dan kerja keras untuk menuhi kebutuhan hidup. Kutipan kitab Amsal menuliskan pada musim dingin si pemalas tidak membajak; jikalau ia mencari pada musim menuai, maka tidak ada

6 Priyono, Priyono, Metode Penelitian Kuantitatif (Sidoarjo: Zifatama Publishing, 2008).

${ }^{7}$ J.R.Raco, Metode Penelitian Kualitatif (Jakarta: Grasindo, 2010). 
PERANAN KEMITRAAN GEREJA DENGAN LEMBAGA KRISTEN ... (Jamsen Ginting, Yanto Paulus

Hermanto, Ferry Simanjuntak)

apa-apa, Amsal 20:4. Ayat tersebut berkaitan dengan profesi petani. Zaman dulu petani dianggap kelas masyarakat yang tidak berpendidikan. Mereka sangat bergantung pada hasil pertanian untuk kelangsungan hidup mereka. Amsal menekankan bahwa sebagai petani bila tidak membajak lahan maka tidak akan menghasilkan apa-apa pada musim menuai. Masyarakat desa yang berprofesi sebagi petani pada saat ini yang masih menggantungkan kelangsungan pada hasil pertanian seperti bawang merah dan hasil kebun seperti sayur-sayuran, juga harus kerja keras mengolah lahan yang mereka miliki. Konteks dalam dunia pertanian, bila tida mengolah lahan tanah untuk ditanami tanaman pangan maka tidak akan menghasilkan apa-apa.

Jemaat gereja yang berprofesi sebagai petani bawang merah di daerah Pati, untuk hidup sehari-hari mereka sangat bergantung pada hasil tanam bawang merah di lahan yang mereka miliki dan harus bekerja keras untuk mencari nafkahnya. Keberhasilan kerja keras ada dalam kedaulatan Tuhan, bekerja keras adalah tugas manusia untuk memenuhi kebutuhannya. Tuhan sudah menyatakan kepada Adam dalam Kejadian 3:17 Lalu firmanNya kepada manusia itu: "Karena engkau mendengarkan perkataan isterimu dan memakan dari buah pohon, yang telah Kuperintahkan kepadamu: Jangan makan dari padanya, maka terkutuklah tanah karena engkau; dengan bersusah payah engkau akan mencari rezekimu dari tanah seumur hidupmu. Sebelum manusia jatuh dalam dosa Tuhan memerintahkan manusia mengelola taman eden, sesudah manusia jatuh dalam dosa manusia bekerja untuk memenuhi kebutuhannya. Konteks kitab Kejadian 3:17 menegaskan bahwa pada dasarnya baik sebelum ataupun sesudah manusia jatuh dalam dosa, manusia sudah ditetapkan Allah untuk bekerja. Pada saat ini manusia tetap harus bekerja, Tuhan memberi kemampuan berpikir dan keahlian dalam bekerja kepada manusia untuk melakukan jenis pekerjaan yang dikuasai.

Tuhan menciptakan manusia dengan talenta untuk membekali manusia dalam menempuh jalan hidup dan kembali memuliakan nama-Nya saat manusia bekerja untuk Kerajaan Allah. Paulus memberi teladan bekerja untuk memenuhi segala kebutuhan hidupnya sehingga tidak menjadi beban bagi jemaat. Paulus menyatakan dalam Kisah Para Rasul 20:34, Kamu sendiri tahu, bahwa dengan tanganku sendiri aku telah bekerja untuk memenuhi keperluanku dan keperluan kawan-kawan seperjalananku. Konteks ayat ini menjelaskan bahwa Paulus tidak mencari kekayaan dalam pelayanannya memberitakan Injil meskipun Paulus memiliki kesempatan yang besar untuk menjadi kaya. Paulus memenuhi panggilan sebagai seorang rasul memiliki pengaruh besar atas banyak orang percaya dengan pelayanan penuh mukjizat kesembuhan. Pada masa itu orang Kristen mula-mula suka memberi uang dan harta kepada orang yang diakui sebagai pimpinan untuk dibagikan kepada mereka yang membutuhkannya. Jikalau Paulus berniat untuk mengambil keuntungan dari pelayanan dalam karunia dan kedudukannya yang didukung oleh kedermawanan orang percaya pada saat itu, Paulus dapat hidup kaya raya. Namun Paulus tidak dilakukannya karena pimpinan Roh Kudus dan kasihnya terhadap Injil. Pada masa sekarang hamba-hamba Tuhan yang melayani di pedesaan dapat menjadikan Paulus sebagai teladan dengan melakukan pekerjaan sesuai dengan kemampuannya dalam memenuhi kebutuhan hidup agar tidak menjadi beban bagi jemaat yang sedang dalam kesulitan keuangan.

\section{Mengubah Pola Berpikir Jemaat yang Keliru}

Anggota jemaat gereja yang tinggal di daerah pedesaan menggantungkan kehidupannya kepada hasil pertanian dan sumber daya lokal yang ada. Pola berpikir dalam bertani bergantung kepada musim hujan, hasil dari produksi yang tidak memiliki kepastian harga jual, menyebabkan kehidupan jemaat dikendalikan oleh pemilik modal. Lembaga Kristen sebelum memberikan dukungan dalam pendampingan, pelatihan dan ketrampilan, 
penyediaan saranan dan prasarana, dukungan modal usaha dan memperluas jaringan dengan pihak-pihak lain perlu melakukan pengembangan pola berpikir gereja dan jemaat bahwa mereka dapat mengolah hasil pertanian yang memiliki nilai jual lebih tinggi dan hasil produksi rumah tangga yang menambah penghasilan. Pola pikir adalah sekumpulan kepercayaan yang mempengaruhi sikap, tindakan, perilaku, keputusan, dan masa depan seseorang. ${ }^{8}$

Mengembangkan pola berpikir jemaat untuk memiliki gagasan dan berkomitmen dalam merealisasikan ide dan gagasan menjadi kenyataan merupakan bagian dari tugas pemimpin gereja. Pemimpin gereja bersama perwakilan Lembaga Kristen memberi kesadaran dan pemahaman baru bagi jemaat bahwa mereka memiliki potensi sumber daya ekonomi yang dapat dikembangkan. Walaupun secara kenyataan keadaan ekonomi dunia sedang tidak baik, namun dalam keyakinan kepada kedaulatan Tuhan tetap ada peluang untuk terjadinya transformasi ekonomi. Menyadarkan gereja dan jemaat bahwa banyak sumber daya ekonomi yang dimiliki gereja yang dapat dikembangkan untuk menghasilkan uang dan meningkatkan pendapatan jemaat. Pemahaman pengembangan diri dan siap terhadap perubahan menjadi dasar dimulainya perubahan pola berpikir. Mendengarkan jemaat membagikan apa yang ada dalam benaknya merupakan langkah awal memulai sebuah perubahan pola berpikir. Saling terbuka dalam mengemukakan pendapat memudahkan pengembangan pola pikir agar siap berubah. Setelah jemaat siap untuk berubah dan mau mengembangkan diri demi kemajuan kearah yang lebih baik, kemudian dilakukan inventarisasi sumber-sumber daya ekonomi yang dapat dieksplorasi yang memiliki nilai ekonomi paling baik.

Suasana ekonomi yang sedang lesu bahkan menuju resesi mengakibatkan setiap orang harus bekerja keras dan kreatif dalam menghadapi persaingan yang semakin kompetitif. Jemaat tetap diyakinkan bahwa peluang ekonomi tetap terbuka sekalipun dimasa resesi dan bisa dimulai dari usaha kecil. Keberadaan usaha-usaha kecil bisa membantu mencukupi kebutuhan keluarga bahkan bisa berdampak pada perekonomian yang lebih besar.

\section{Kerjasama Kemitraan Gereja dengan Lembaga Kristen}

Kehadiran Lembaga Kristen mendampingi gereja dan jemaat dianggap cukup representatif dalam memberdayakan ekonomi jemaat dan masyarakat. Pendampingan terhadap gereja akan menjaga gereja tetap berada dikoridor Tuhan dan juga mengakomodir kebutuhan jemaat. Gereja membangun kerjasama kemitraan sebagai upaya mengembangkan usaha kecil dikalangan umat dimana gereja berada dan secara intensif kerjasama menolong jemaat meningkatkan pendapatan. Realita yang ada gereja adalah lemah dan berada di ambang jurang finansial, pendeta yang tidak memahami masalah ekonomi dan lemah dalam visi yang berkaitan dengan keuangan. Melihat kondisi gereja Indonesia dengan banyaknya anggaran yang dihabiskan untuk bangunan gereja yang digunakan dan untuk tempat kebaktian gereja seperti menyewa ruangan di hotel, toko, atau kantor, termasuk menggunakan sekolah Kristen untuk ibadah dan pertemuan gereja, membuat gereja sibuk dengan masalah internal.

Pendampingan gereja dalam pengembangan kehidupan jemaat akan menyadarkan gereja bahwa peran gereja untuk menolong jemaat yang dalam kesulitan keuangan perlu mendapat porsi perhatian yang besar yang melibatkan peran serta pihak eksternal gereja sesuai dengan kebutuhan pengembangan yang akan dilakukan. Keterlibatan gereja dalam mengembangkan jemaat akan terlihat oleh jemaat dan orang-orang di luar gereja.

8 Tung Desem Waringin dan Ongky Hojanto, Financial Revolution in Action (Jakarta: Kompas Gramedia, 2013). 
PERANAN KEMITRAAN GEREJA DENGAN LEMBAGA KRISTEN ... (Jamsen Ginting, Yanto Paulus

Hermanto, Ferry Simanjuntak)

Pendampingan terhadap pemimpin gereja mulai dari Pendeta dan jajarannya bermaksud untuk mengembangkan para pemimpin dalam pengembangan visi, memperluas wawasan dan jangkauan pelayanan, pendampingan terhadap jemaat. Pemimpin gereja memiliki pengaruh besar kepada jemaat meningkatkan pengetahuan tentang potensi gereja dan jemaat untuk mengembangkan visi masa depan. Untuk mencapainya perlu keterlibatan berbagai kalangan mendampingi gereja dalam peningkatan pengetahuan, pencarian modal, pelatihan ketrampilan dan keahlian. ${ }^{9}$

\section{Pondasi Kerjasama Kemitraan}

Kerjasama dalam kemitraan dilakukan melalui tahapan komunikasi awal, sosialisasi visi dan misi, memahami dan memiliki tujuan bersama, sepakat terhadap hak dan kewajiban, memiliki panduan kerja bersama, memiliki tujuan yang sama dalam meningkatkan pendapatan jemaat gereja, membuat dokumen rencana kerja dan rencana biaya untuk mencapai hasil yang disepakati dan diimplementasi bersama, monitor dan evaluasi melalui laporan dan audit. Adapun prinsip kemitraan mencakup kesatu, saling membutuhkan; kedua, saling mendukung dan menguatkan; ketiga, saling menguntungkan. Dasar Kemitraan, yaitu: 1) adanya kebutuhan yang dirasakan oleh pihak yang akan bermitra; 2) adanya persoalan internal dan eksternal usaha yang dihadapi dalam mengembangkan usaha; 3) kegiatan yang dijalankan dapat memberikan manfaat yang nyata yang bersifat "Mutual benefit bagi pihak-pihak yang bermitra."10

Menjalankan prinsip kemitraan, perlu integritas yang tinggi para pemimpin gereja untuk membangung rasa saling percaya dalam kemitraan. Integrity means behaving the same way all the time, whether or not others can see you. And it is one of the greatest challenges of leadership, especially for those whose influence grows and who become wellknown public figures. ${ }^{11}$ Artinya, integritas artinya berperilaku sama yang sama setiap waktu, meskipun tidak ada yang melihat anda. Dan hal ini menjadi tantangan terbesar dari kepemimpinan, khususnya bagi mereka yang mempengaruhi pertumbuhan dan yang menjadi tokoh publik yang dikenal baik. Integritas menjadi pondasi dasar yang tidak dapat ditawar ketika gereja berbicara tentang usaha untuk meningkatkan sumber daya keuangan. Usaha untuk meningkatkan pendapataan jemaat dilakukan melalui pemberdayaan jemaat melakukan usaha kecil dengan mobilisasi sumber-sumber ekonomi yang dapat menghasilkan uang.

Upaya peningkatan ekonomi jemaat gereja akan membuka kesempatan kerja bagi jemaat, meningkatkan ketahanan ekonomi jemaat sekaligus menjalankan misi dalam menggenapi Amanat Agung, Matius 28:19-20. Allah adalah Allah yang misioner dan penyelamatan-Nya ditujukan bagi dunia bukan hanya bagi gereja. Gereja selalu melakukan misi. Tindakan tersebut berdasar pada pemahaman misi sebagai sifat alamiah gereja. ${ }^{12}$ Peran Lembaga Kristen dalam memberikan bimbingan dan meningkatkan kualitas Sumber Daya Manusia dapat melahirkan pengusaha kecil diberbagai bidang. Kehadiran Lembaga Kristen dalam mendampingi gereja untuk memberikan akses kepada gereja dalam mencari modal dasar usaha, pelatihan ketrampilan dan keahlian, kemampuan manajemen dan keuangan, serta akses kerjasama lebih luas dengan berbagai pihak. Kemitraan antara

\footnotetext{
9 Peter Dekker, "Entrepreneurship and the Relation with Mission in the Church of Indonesia," Jurnal Jaffray 18 (2020): 186, https://ojs.sttjaffray.ac.id/JJV71/article/view/437/pdf_204

10 Ratih Tresnati, "KAJIAN TENTANG KEMITRAAN GUNA MENINGKATKAN PENDAPATAN PETANI PADA USAHATANI JAGUNG MANIS DI KABUPATEN CIAMIS,” Performa 11 (2014): 5, https://ejournal.unisba.ac.id/index.php/performa/article/view/3031/1899

11 Jane Overstreet, Unleader (Illionis: InterVarsity Press, 2011).

12 Rut Debora Butar-butar dan Raharja Sembiring Milala, "Dari Church Planting Ke Hospitalitas: Rekonstruksi Misi Gereja Dalam Konteks Keberagaman,” Epigraphe 4 (2020): 177, http://www.stttorsina.ac.id/jurnal/index.php/epigraphe/article/view/191/57
} 
gereja dengan Lembaga Kristen dalam meningkatkan pendapatan jemaat menjadi sumber motivasi bagi gereja dan jemaat dalam menggali potensi ekonomi lokal yang berorientasi pada nilai keuntungan dari pasar hasil produk jasa dan barang.

Kemitraan yang dibangun adalah pendampingan terhadap gereja dan jemaat dalam memulai usaha kecil barang dan jasa yang menguntungkan secara ekonomi. Undangundang mengatur aktifitas yang bertujuan ekonomi dengan skala kecil yang sesuai kriteria menurut nilai harta bersih dan transaksi penjualan per tahun serta nilai kekayaan yang dimiliki sebagai usaha kecil. ${ }^{13}$ Gereja dan Lembaga Kristen yang mendampingi masingmasing memiliki prinsip dasar berorientasi pada hasil yang diharapkan dan disepakati bersama, saling membutuhkan dan menguatkan, saling menguntungkan kedua belah pihak. Dengan demikian kerjasama dalam bentuk bermitra usaha kecil menengah harus didasarkan atas prinsip sinergi, yaitu saling membutuhkan dan saling membantu. Prinsip saling membutuhkan. Secara langsung pihak yang bekerjasama memunculkan prinsip saling membantu. ${ }^{14}$

Kemitraan dibangun untuk menjawab permasalahan yang dihadapi oleh jemaat gereja, didukung program yang selaras dari Lembaga Kristen dan memberikan manfaat nyata bagi kedua belah pihak. Pengembangan Kemitraan selanjutnya mengarah kepada pengembangan usaha kecil dan pendampingan pemasaran produk dalam skala usaha kecil yang berorientasi pada permintaan pasar. Bank Indonesia menetapkan kriteria usaha kecil mencakup: kesatu, kekayaan bersih maksimal dua ratus juta rupiah; kedua, hasil transaksi penjualan pertahun maksimal satu miliar rupiah; ketiga, usaha adalah miliki warga Indonesia; keempat, usaha berdiri sendiri tanpa afiliasi; kelima, berupa usaha perorangan yang berbadan hukum ataupun tidak berbadan hukum. ${ }^{15}$

\section{Implementasi Kerjasama Kemitraan}

Pendampingan Lembaga Kristen yang dilakukan kepada gereja sesuai dengan potensi ekonomi yang ada di mana gereja dan jemaat berada. Pengembangan sumber daya manusia dalam keterampilan dan keahlian bidang khusus, manajemen, monitoring dan evaluasi sangat penting bagi gereja untuk dapat bekerjasama dalam kemitraan. Faktor-faktor tersebut terkait dengan prinsip dasar pengembangan etika bisnis, antara lain mencakup: sumber daya manusia, manajemen dan teknis pelaksanaan kemitraan, mental dan sikap pelaksana kemitraan, keterlibatan pelaksana kemitraan, masalah lingkungan dan keamanan, fasilitas/sarana dan prasarana, serta peraturan daerah dan pusat. ${ }^{16}$ Implementasi pelaksanaan program membutuhkan komitmen kuat kedua belah pihak untuk saling mendukung dan saling melengkapi. Lembaga Kristen memegang peranan penting dalam menjaga komitmen untuk memastikan gereja dan jemaat benar-benar menjalankan komitmen yang disepakati sebelumnya. Meskipun begitu, tanggung jawab sepenuhnya diserahkan kepada gereja dan jemaat untuk melaksanakan program.

\footnotetext{
13 Kemenkeu, UU No. 9 Tahun 1995 Tentang Usaha Kecil, 1995,

https://jdih.kemenkeu.go.id/fulltext/1995/9TAHUN 1995UU

14 Saparuddin M. dan Basri Bado, "PENGARUH KEMITRAAN USAHA TERHADAP KINERJA USAHA PADA USAHA KECIL MENENGAH (UKM) DAN KOPERASI DI KABUPATEN JENEPONTO SULAWESI SELATAN,” econosains IX (2011): 165, http://journal.unj.ac.id/unj/index.php/econosains/article/view/626

15 Bank Indonesia, Surat Edaran Bank Indonesia No. 3/9/Bkr Tahun 2001, 2001, https://www.bi.go.id/id/peraturan/arsip-peraturan/Perbankan2001/SE Eks 03009 BKr.PDF

${ }^{16}$ Raja B. D. Sormin dan Stenly J. Ferdinandus1) Agustina Risambessy, "STRATEGI KEMITRAAN DALAM MENINGKATKAN DAYA SAING USAHA PENGOLAHAN DAN PEMASARAN RUMPUT LAUT DI WILAYAH KOTA AMBON DAN KABUPATEN MALUKU TENGGARA BARA," FEB Unsoed (n.d.): 198, http://jp.feb.unsoed.ac.id/index.php/sca-1/article/viewFile/925/pdf_133.
} 
PERANAN KEMITRAAN GEREJA DENGAN LEMBAGA KRISTEN ... (Jamsen Ginting, Yanto Paulus Hermanto, Ferry Simanjuntak)

Penulis terlibat dalam pendampingan gereja di daerah Pati, Purbalingga, dan Ungaran dengan mengembangkan potensi ekonomi dimasing-masing daerah tersebut. Jemaat gereja wilayah Pati memiliki usaha pertanian bawang merah. Harga bawang merah yang tidak stabil dan cenderung turun pada saat panen raya sangat merugikan petani bawang merah. Berdasarkan hasil diskusi dengan pemimpin gereja dan jemaat petani bawang merah, dikembangkan pengolahan bawang merah menjadi bawang goreng. Lembaga Kristen mencari donatur untuk memberi modal awal berupa alat pengolahan dan produksi bawang goreng. Gereja meyediakan tempat untuk mengolah bawang hasil panenan jemaat termasuk mengkoordinasi jemaat untuk melakukan pengolahan bawang di rumah-rumah jemaat. Setiap kali jemaat panen bawang merah, hasil panenan diarahkan untuk diolah menjadi bawang goreng. Masing-masing jemaat membuat bawang goreng, dikemas dengan baik dan membuat merek dagang mereka sendiri setelah hasil produksi bawang goreng didaftarkan Secara resmi ke dinas terkait. Hasil pengolahan bawang goreng memiliki nilai jual yang lebih mahal, lebih tahan lama dan lebih menguntungkan petani karena tidak bergantung pada naik turunnya harga bawang merah. Pendapatan jemaat gereja saat ini meningkat seiring dengan pertumbuhan jumlah produksi bawang goreng yang dilakukan.

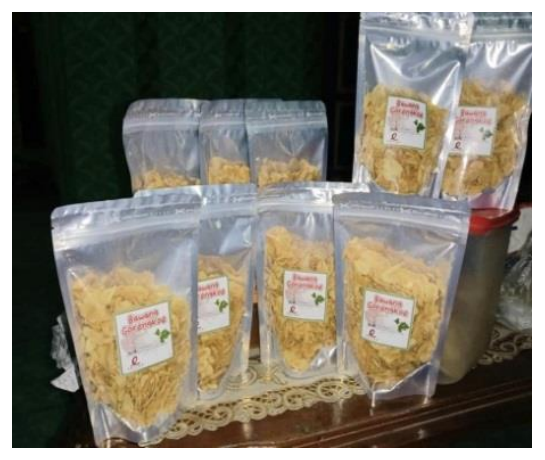

Penulis mendampingi jemaat gereja di wilayah Purbalingga dalam mengelola kebutuhan air dan lahan tidur yang tidak produktif. Pekarangan rumah yang luas, kebun jemaat yang belum digarap menjadi fokus potensi ekonomi yang digarap. Lembaga Kristen melihat kendala pengolahan lahan adalah ketersediaan air pada musim kemarau. Pendampingan gereja dilakukan dengan menyediakan sumur bor di gereja yang dapat disalurkan untuk memenuhi kebutuhan air masyarakat dan kebutuhan air dalam mengolah lahan tidur. Gereja menyediakan tempat untuk pengeboran air, menyiapkan tenaga dari jemaat yang ahli mencari sumber air sebelum melakukan pengeboran, serta melakukan koordiansi dengan semua pihak terkait sampai air tersedia. Jemaat gereja mendapatkan air tanpa mengeluarkan biaya dan mengembangkan tanaman sayur mayur yang dapat dipanen dalam waktu dua minggu sampai tiga bulan. Hasil panen kebun dipekarangan rumah dan dikebun jemaat dapat memenuhi kebutuhan keluarga jemaat dan meningkatkan pendapatan jemaat melalui penjualan cabe, tomat, bayem, dan sayur-sayuran lainnya.

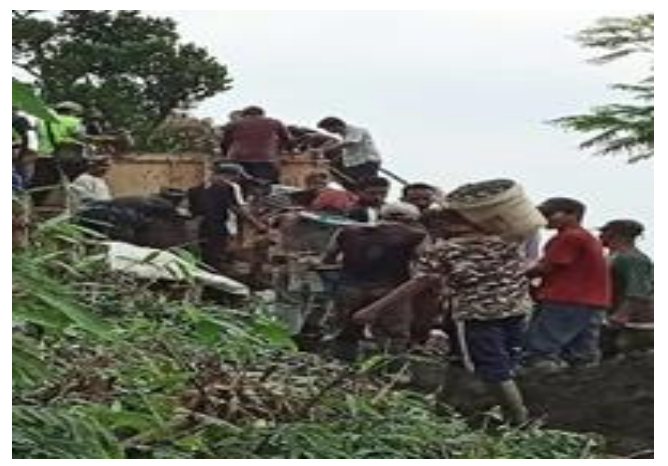


Pendampingan Lembaga Kristen terhadap gereja di Ungaran dilakukan bagi jemaat pemuda untuk mengembangkan usaha konveksi. Jemaat gereja yang banyak bekerja sebagai buruh pabrik konveksi memiliki keahlian dalam menjahit, membuat pola dan memilih bahan yang baik. Pendampingan dilakukan dengan penyediaan mesin jahit, mesin obras, peralatan konveksi dan bahan-bahan yang dibutuhkan sebagai modal awal. Jemaat menyediakan tempat untuk memulai usaha konveksi. Jemaat pemuda yang kreatif dan mendapatkan kesempatan usaha, memulai memproduksi kaos dan seragam olah raga dari berbagai cabang olah raga. Dukungan gereja dan orang tua memudahkan kaum muda berkreasi model dan motif yang mengikuti trend mode baju kaos. Kualitas yang dijaga, harga yang terjangkau dan pemasaran secara online/offline membuka peluang semakin lebar dan meningkatkan hasil produksi. Kaum muda gereja yang sudah lulus SMA/SMK semula menganggur mulai memiliki aktifitas produksi yang menghasilkan uang.
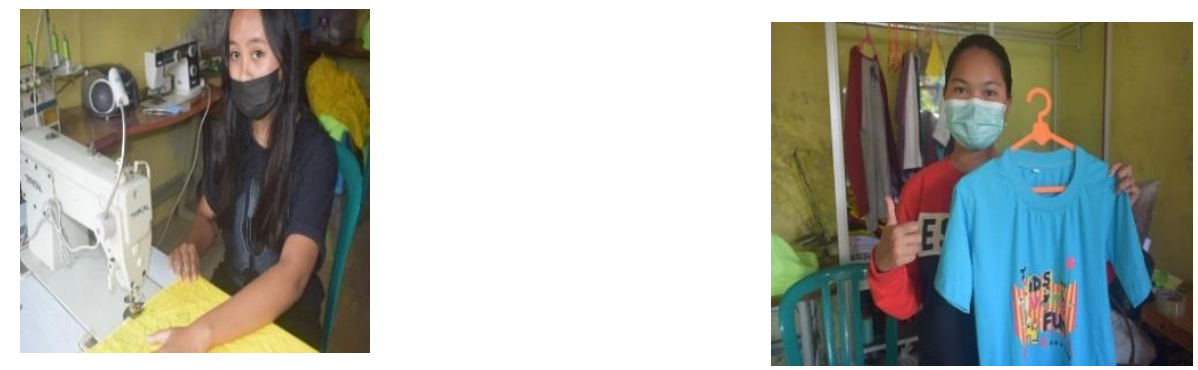

\section{KESIMPULAN}

Menghadapi krisis ekonomi dan resesi global yang melanda dunia dan bangsa Indonesia, serta berdampak terhadap penurunan pendapatan jemaat gereja secara umum, dibutuhkan langkah-langkah strategis yang harus diambil gereja untuk menolong jemaat. Menggali potensi ekonomi yang ada di lingkungan gereja dan tempat tinggal jemaat merupakan salah satu langkah strategis yang dapat dilakukan. Keterbatasan sumber daya gereja baik sumber daya manusia maupun keuangan, dapat diatasi dengan menggandeng pihak eksternal gereja untuk mengembangkan sumber daya manusia dan sumber keuangan. Kerjasama kemitraan dengan pihak eksternal gereja lebih mudah dilakukan bila memiliki nilai-nilai kebenaran yang sama-sama berpusat pada Kristus. Oleh sebab itu gereja bekerjasama dengan Lembaga Kristen yang memiliki tujuan yang sama yaitu untuk meningkatkan pendapatan jemaat dengan menolong gereja dalam mengembangkan sumber daya manusia dan menggali potensi ekonomi lokal. Lembaga Kristen yang diajak kerjasama diharapkan dapat mengidentifikasi potensi ekonomi dan tantangan dalam memobilisasi sumber-sumber daya setempat.

Kerjasama dalam kemitraan gereja dengan Lembaga Kristen menjadi sangat efektif bila dilakukan pada saat kedua belah pihak memiliki tujuan yang sama, proses pelaksaan program yang disepakati, penanganan masalah atas dasar identifikasi masalah dan melakukan analisa kebutuhan. Gereja memiliki sumber daya manusia, sumber daya alam sebagai modal dasar pengembangan ekonomi, disisi yang lain Lembaga Kristen memiliki sumber daya keuangan, teknologi, keterampilan dan keahlian dalam pengelolaan program. Masing-masing pihak memiliki tujuan yang sama untuk meningkatkan pendapatan jemaat gereja. Perpaduan dua kekuatan sumber daya yang dimiliki membuka peluang usaha bagi jemaat untuk menghasilkan uang. Jemaat yang mau dikembangkan kemampuannya akan melihat peluang usaha sesuai dengan konteks jemaat itu sendiri, sehingga memiliki sumber 
PERANAN KEMITRAAN GEREJA DENGAN LEMBAGA KRISTEN ... (Jamsen Ginting, Yanto Paulus

Hermanto, Ferry Simanjuntak)

pendapatan baru disamping pendapatan yang sudah ada. Jemaat gereja dapat mengeksplorasi semua sumber daya yang ada ditempat tinggal masing-masing.

Melalui hasil pendampingan terhadap jemaat gereja di wilayah Pati, Purbalingga dan Ungaran, masih dapat dilakukan pengembangan jemaat untuk meningkatkan pendapatan jemaat dengan memanfaatkan potensi ekonomi loka yang ada dengan tujuan menghasilkan uang dan penghasilan meningkat. Gereja berperan membangun kerjasama kemitraan dengan Lembaga Kristen, melakukan koordinasi dalam pemimpin gereja dan jemaat, penyediaan sarana prasarana gereja bagi jemaat, pengurusan legalitas dan administrasi, sejak perencanaan sampai kemitraan mendapatkan hasil yang nyata melalui program yang dilaksanakan. Pengembangan jemaat dalam menggali potensi-potensi yang ada dilakukan melalui tahapan proses yang terencana sampai menjadi sumber penghasilan baru, akan berdapak luas dan terjadi multiplikasi jumlah jemaat yang terlibat dalam program pengembangan. Jemaat yang sudah berhasil dapat membina jemaat yang baru memulai dan dilakukan secara berkesinambungan yang dapat menjangkau masyarakat disekitar lingkungan tempat tinggal dan lingkungan gereja. Keberhasilan gereja dalam membina jemaat bahkan masyarakat untuk meningkatkan pendapatan mereka, akan menjadi berkat bagi banyak orang. Itulah saat gereja menjadi terang dan garam ditengah masyarakat.

\section{DAFTAR PUSTAKA}

Agustina Risambessy, Raja B. D. Sormin dan Stenly J. Ferdinandus1). "STRATEGI KEMITRAAN DALAM MENINGKATKAN DAYA SAING USAHA PENGOLAHAN DAN PEMASARAN RUMPUT LAUT DI WILAYAH KOTA AMBON DAN KABUPATEN MALUKU TENGGARA BARA." FEB Unsoed (n.d.): 198. http://jp.feb.unsoed.ac.id/index.php/sca1/article/viewFile/925/pdf_133

Bank Indonesia. Surat Edaran Bank Indonesia No. 3/9/Bkr Tahun 2001, 2001. https://www.bi.go.id/id/peraturan/arsip-peraturan/Perbankan2001/SE Eks 03009 BKr.PDF.

Dosen Prodi Karya Tulis Ilmiah Program Magister Teologi Sekolah Tinggi Teologia Kharisma Bandung.

Dosen Wali Program Magister Teologi Sekolah Tinggi Teologi Kharisma Bandung.

J.R.Raco. Metode Penelitian Kualitatif. Jakarta: Grasindo, 2010.

Jane Overstreet. Unleader. Illionis: InterVarsity Press, 2011.

Jeff Manion. The Land Between: Finding God in Difficult Situation. Michigan: Zondervan, 20012.

John Ortberg. Soul Keeping. Michigan: Zondervan, 2014.

Kemenkeu. UU No. 9 Tahun 1995 Tentang Usaha Kecil, 1995.

https://jdih.kemenkeu.go.id/fulltext/1995/9TAHUN 1995UU.

Kerry Patterson, Joseph Grenny, and Al Switzler; Ron McMilla and. Crucial Conversation.

The Mcgraw Hills Companies, 2012.

Niko Njotorahardjo. Mujizat Masih Ada. Jakarta: Divisi Pengajaran GBI Gatot Subroto, 2013.

Peter Dekker. "Entrepreneurship and the Relation with Mission in the Church of

Indonesia." Jurnal Jaffray 18 (2020): 186.

https://ojs.sttjaffray.ac.id/JJV71/article/view/437/pdf_204.

Petrus Simon. "Tanggapan Alkitab Terhadap Wacana Hukuman Mati Bagi Pelaku Korupsi." Kenosis 6 (2020): 109. https://e-

journal.iaknambon.ac.id/index.php/KNS/article/view/87/126.

Priyono. Priyono, Metode Penelitian Kuantitatif. Sidoarjo: Zifatama Publishing, 2008.

Ratih Tresnati. "KAJIAN TENTANG KEMITRAAN GUNA MENINGKATKAN PENDAPATAN PETANI PADA USAHATANI JAGUNG MANIS DI KABUPATEN CIAMIS.” Performa 11 
(2014): 5 .

https://ejournal.unisba.ac.id/index.php/performa/article/view/3031/1899

Rut Debora Butar-butar dan Raharja Sembiring Milala. "Dari Church Planting Ke

Hospitalitas: Rekonstruksi Misi Gereja Dalam Konteks Keberagaman." Epigraphe 4 (2020): 177.

http://www.stttorsina.ac.id/jurnal/index.php/epigraphe/article/view/191/57

Saparuddin M. dan Basri Bado. "PENGARUH KEMITRAAN USAHA TERHADAP KINERJA

USAHA PADA USAHA KECIL MENENGAH (UKM) DAN KOPERASI DI KABUPATEN

JENEPONTO SULAWESI SELATAN." econosains IX (2011): 165.

http://journal.unj.ac.id/unj/index.php/econosains/article/view/626.

Tung Desem Waringin dan Ongky Hojanto. Financial Revolution in Action. Jakarta: Kompas Gramedia, 2013.

Mahasiswa Program Magister Teologi Sekolah Tinggi Teologi Kharisma Bandung. 